\title{
Analytical hierarchy process for regional development priority in Donorejo, Central Java
}

\author{
Rahma Aulia Zahra, Muhammad Galih Prakosa, Eunike Olivia Danni Kusuma, Ismanita Prahara, Benaya Valentino \\ Ginting, Rahmatullah Tri Nanda Putra, Emilya Nurjani and Ratih Fitria Putri*
}

Department of Environmental Geography, Faculty of Geography, Universitas Gadjah Mada, Indonesia

\begin{abstract}
Donorejo is one of the villages in Purworejo Regency, Central Java, Indonesia. This village is a unique place and famous for its tourism site, namely Goa Seplawan. Nevertheless, this tourist attraction has not provided significant income for local revenue, as the poverty rate in Donorejo is still quite high. The Office of Community Empowerment, Villages, Population and Civil Registry of Central Java stated that only 1,630 residents of Donorejo were categorized as prosperous in their economy. It indicated that almost $50 \%$ of the population in Donorejo has not been economically prosperous and the development of Donorejo has not implemented optimally. To find out the proper development strategy, the Analytical Hierarchy Process was used as a method based on stakeholder assessment in the Donorejo. The used priorities were based on four aspects, namely human resource development, regional promotion, development of supporting infrastructure, and public services. The obtained results indicated that development of supporting infrastructure is a priority for the development of Donorejo. This outcome can be used as a reference to optimize the village development.
\end{abstract}

\section{Introduction}

Donorejo is one of the villages in Purworejo Regency, Central Java Province, Indonesia. This region has a lot of tourism potential, such as mountain tourism, historical sites, waterfalls, and caves [1]. Its location in the karst landscape makes Donorejo has many caves [2]. Goa Seplawan is one of the biggest and famous caves in Donorejo and is included as the Enchantment of Indonesia. This cave is one of the commercial attractions in Purworejo Regency [3]. The location of the cave in the hilly region becomes an added value because the attractions presented to visitors are various. The attractions are the cave itself, the scenery, and there are Hindu cultural heritage sites such as the discovery of gold statues and remnants of buildings with high historical value.

Goa Seplawan was having an increasing number of visitors from both local and other regions in the last few years. However, this increasing number of visitors did not have much impact on the economy of the Donorejo communities. Besides, Donorejo also has the potential for agriculture as shown in Figure 1. Nevertheless, the lack of infrastructure and resources also make this sector has not optimally developed. The Office of Community Empowerment, Villages, Population and Civil Registry of Central Java Province stated that only 1,630 residents from total population in Donorejo were classified as prosperous in economy.
This data indicated that almost $50 \%$ of the population in Donorejo has not been economically prosperous and the development of Donorejo has not implemented optimally. Analytical Hierarchy Process is one of the proper methods to assess development strategies. This method is based on the most important and influential parameters of development. The assessment is done based on village's stakeholders to obtain the development strategy priorities for Donorejo.

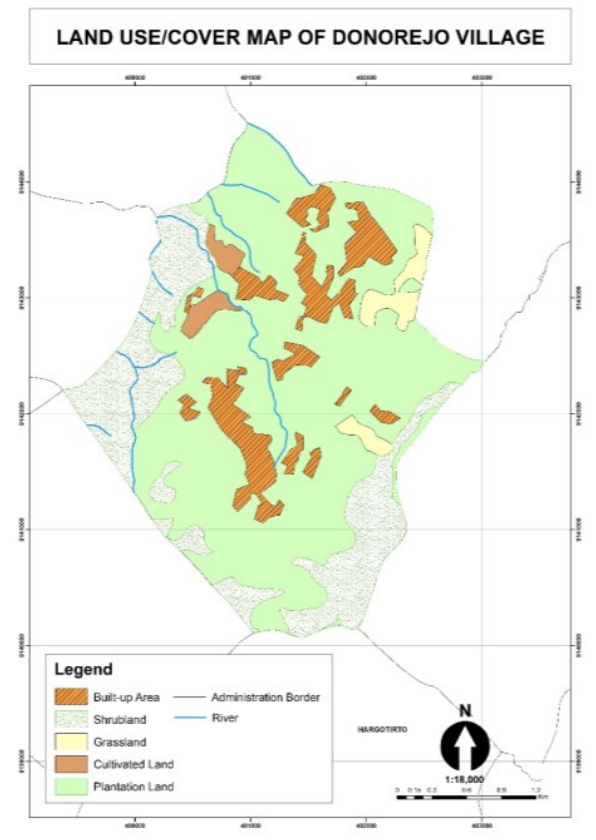

Fig.1. Map of Donorejo

\footnotetext{
* Corresponding author: ratihfitria.putri@ugm.ac.id
} 


\section{Methodology}

\subsection{Analytical hierarchy process}

Analytical Hierarchy Process (AHP) is a method used in solving problems by using ranking or prioritizing parameters. AHP can be used in determining development priorities, for example in Maluku Province [4]. AHP is a qualitative method with mathematical calculations by comparing criteria in pairs [5]. AHP helps simplify complex decisions and unstructured situations by assigning weights to each variable or parameter that is considered important [6]. The stages in this method are determining the most important parameter in village development, then giving weight to each parameter that has been determined. The emergence of parameter answered by respondents will indicate the priority parameters in the development of Donorejo.

\subsection{Parameters}

There are several parameters which can be used as priorities in regional development, namely human resource development, regional promotion, development of supporting infrastructure, and public services [7].

\subsubsection{Human Resource Development}

Human resource development is the development of management related to human resource (HR) themselves. The use of high technology is meaningless without HR, so it is one of the parameter that needs attention in development. Human resource development is intended to deal with problems in all fields of work, such as employees, managers, farmers and other occupation. Proper human resources will manage the institution significantly. Improvement and development of human resource can be done by improving education or training.

\subsubsection{Regional Promotion}

Promotion is every marketing effort that serves to provide information about a product or service to make a profit. Regional promotion can be done in some ways, such as regional marketing, regional master plan, and e-marketing. According to UNWTO, regional marketing like the existence of traditional arts can attract visitors [8].

\subsubsection{Development of Supporting Infrastructure}

One of the policy strategies is providing and maintaining physical infrastructure [7]. Infrastructure is a basic element of an area which is formed as building or physical facility developed to support the achievement of the social and economic goals of a community. The policy implications can be applied in many ways, such as road repair and widening, road lighting provision, and road maintenance [9]. This parameter is considered important based on data from the Village Profile of Donorejo which shows that 5 out of $10 \mathrm{~km}$ of roads in Donorejo were damaged, including the road to Seplawan Cave as the biggest tourist attraction. Other infrastructure also plays a large role in regional development. This was proven by previous research which showed an increase in Goa Seplawan visitors due to infrastructure improvements such as the viewing gates in 2013-2015 [10]. This shows a positive significance due to the construction of various infrastructures in Donorejo.

\subsubsection{Public Service}

Public service is the provision of services for community needs in organization which are in accordance with the basic rules and procedures. Good public services are characterized by accountability and responsibility from providers' service (government). Aspects of public service have two criteria in the development of the region, namely the licensing and the consolidation of the law [6]

\subsection{Respondents}

Literature review, observation, and interview were done to collect the data in this research. Interviews were conducted directly with residents and stakeholders with the aim of getting the right information from trusted informants. Respondents in this study were stakeholders who were chosen in each hamlet in Donorejo. The selection of respondents is aimed to make the information more accurate and reliable. Respondents were taken as 5 stakeholders in each hamlet to represent all residents in Donorejo.

\subsection{Research flowchart}

The stages of processing during the study is represented by the flow chart in Figure 2.

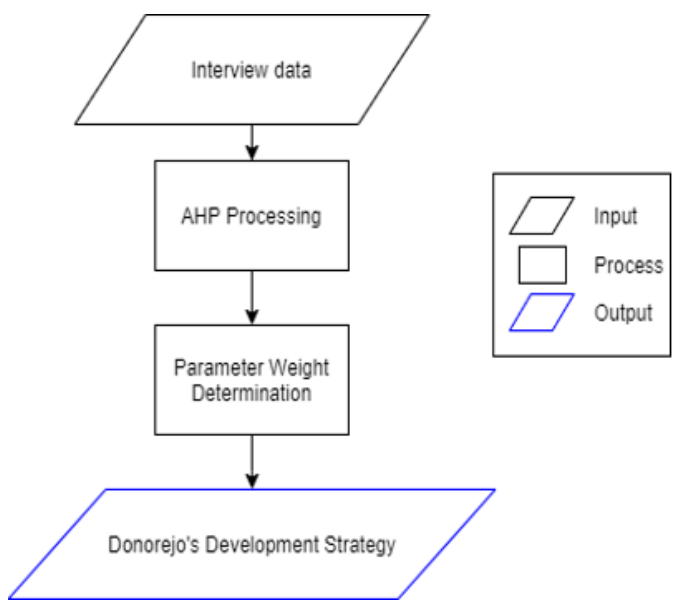

Fig.2. Work Steps of the Priority Development Research of Donorejo 


\section{Results and discussion}

The Donorejo development strategy is determined through the Analytical Hierarchy Process (AHP) method. The data collection of this research was carried out by interviewing and discussing with stakeholders in Donorejo with a total of five respondents. The discussion was carried out by determining the priority parameters of the development sector for each respondent. The parameters used in this research are human resource development, regional promotion, development of supporting infrastructure, and public services. The results of the discussion then processed through the Analytical Hierarchy Process (AHP) method with a decision matrix and produce weights based on the principal eigenvector of the decision matrix. Weights results are ranking priorities for development parameters.

Based on the results of the respondents' discussion and the results of the Analytical Hierarchy Process (AHP) method, several priority rankings were generated for each respondent. P1 shows the development of human resources, P2 shows regional promotion, P3 shows the development of supporting infrastructure, and $\mathrm{P} 4$ shows public service. The results of development priorities from the first respondent is shown in Table 1. The development of supporting infrastructure ranked first with a priority weight of 0.651 followed by public service with a priority weight of 0.187 . The third human resource development with a weight of 0.093 , and the last regional promotion with a priority weight of 0.070 .

Table 1. Calculation of the total weight of the parameters (Respondent 1)

\begin{tabular}{ccccc}
\hline Indicator & P1 & P2 & P3 & P4 \\
\hline P1 & 1.00 & 1.00 & 0.14 & 1.00 \\
P2 & 1.00 & 1.00 & 0.14 & 0.14 \\
P3 & 7.00 & 7.00 & 1.00 & 7.00 \\
P4 & 1.00 & 7.00 & 0.14 & 1.00 \\
\hline \multicolumn{4}{l}{ Source: Donorejo's Stakeholder Interview Data, 2020 }
\end{tabular}

Table 2. Normalized Data (Respondent 1)

\begin{tabular}{cccccc}
\hline Indicator & P1 & P2 & P3 & P4 & Weight \\
\hline P1 & 0,100 & 0,063 & 0,100 & 0,109 & 0,093 \\
P2 & 0,100 & 0,063 & 0,100 & 0,016 & 0,070 \\
P3 & 0,700 & 0,438 & 0,700 & 0,766 & 0,651 \\
P4 & 0,100 & 0,438 & 0,100 & 0,109 & 0,187 \\
\hline \multicolumn{5}{r}{ Source: Donorejo's Stakeholder Interview Data, 2020 }
\end{tabular}

The results of the development priorities from the second respondent are shown in Table 4. The public service parameter is ranked first with a weight of 0.435 followed by a regional promotion parameter with a priority weight 0.320 . The third is human resource development which is weighted 0.164 and the last is the development of supporting infrastructure with a priority weight 0.081 .
Table 3. Calculation of the total weight of the parameters (Respondent 2)

\begin{tabular}{ccccc}
\hline Indicator & P1 & P2 & P3 & P4 \\
\hline P1 & 1.00 & 0.20 & 1.00 & 1.00 \\
P2 & 5.00 & 1.00 & 5.20 & 0.20 \\
P3 & 1.00 & 0,20 & 1.00 & 0.20 \\
P4 & 1.00 & 5.00 & 5.00 & 1.00 \\
\hline \multicolumn{4}{l}{ Source: Donorejo's Stakeholder Interview Data, 2020 }
\end{tabular}

Table 4. Normalized Data (Respondent 2)

\begin{tabular}{cccccc}
\hline Indicator & P1 & P2 & P3 & P4 & Weight \\
\hline P1 & 0,125 & 0,031 & 0,083 & 0,417 & 0,164 \\
P2 & 0,625 & 0,156 & 0,417 & 0,083 & 0,320 \\
P3 & 0,125 & 0,031 & 0,083 & 0,083 & 0,081 \\
P4 & 0,125 & 0,781 & 0,417 & 0,417 & 0,435 \\
\hline
\end{tabular}

Source: Donorejo's Stakeholder Interview Data, 2020

The results of development priorities from the third respondent are shown in Table 6 . The results are slightly different from other respondents where the regional promotion and the development of supporting infrastructure are both ranked first with a priority weight 0.408 . This weight is followed by the public service with a priority weight 0.125 . The last is the human resource development with a priority weight 0.059 .

Table 5. Calculation of the total weight of the parameters (Respondent 3)

\begin{tabular}{ccccc}
\hline Indicator & P1 & P2 & P3 & P4 \\
\hline P1 & 1,00 & 0,17 & 0,17 & 0,33 \\
P2 & 6,00 & 1,00 & 1,00 & 4,00 \\
P3 & 6,00 & 1,00 & 1.00 & 4.00 \\
P4 & 3.00 & 0.25 & 0.25 & 1.00 \\
\hline \multicolumn{4}{l}{ Source: Donorejo's Stakeholder Interview Data, 2020 }
\end{tabular}

Source: Donorejo's Stakeholder Interview Data, 2020

Table 6. Normalized Data (Respondent 3)

\begin{tabular}{cccccc}
\hline Indicator & P1 & P2 & P3 & P4 & Weight \\
\hline P1 & 0,063 & 0,069 & 0,069 & 0,036 & 0,059 \\
P2 & 0,375 & 0,414 & 0,414 & 0,429 & 0,408 \\
P3 & 0,375 & 0,414 & 0,414 & 0,429 & 0,408 \\
P4 & 0,188 & 0,103 & 0,103 & 0,107 & 0,125 \\
\hline
\end{tabular}

Source: Donorejo's Stakeholder Interview Data, 2020

The results of the development priorities from the fourth respondent are shown in Table 8 . The development of supporting infrastructure is ranked first with a priority weight 0.7 . Other parameters including human resource development, regional promotion, and public services having the same weight of 0.1 . 
Table 7. Calculation of the total weight of the parameters (Respondent 4)

\begin{tabular}{ccccc}
\hline Indicator & P1 & P2 & P3 & P4 \\
\hline P1 & 1,00 & 1,00 & 0,14 & 1,00 \\
P2 & 1,00 & 1,00 & 0,14 & 1,00 \\
P3 & 7,00 & 7,00 & 1.00 & 7.00 \\
P4 & 1.00 & 1.00 & 0.14 & 1.00 \\
\hline
\end{tabular}

Source: Donorejo's Stakeholder Interview Data, 2020

Table 8. Normalized Data (Respondent 4)

\begin{tabular}{cccccc}
\hline Indicator & P1 & P2 & P3 & P4 & Weight \\
\hline P1 & 0,100 & 0,100 & 0,100 & 0,100 & 0,100 \\
P2 & 0,100 & 0,100 & 0,100 & 0,100 & 0,100 \\
P3 & 0,700 & 0,700 & 0,700 & 0,700 & 0,700 \\
P4 & 0,100 & 0,100 & 0,100 & 0,100 & 0,100 \\
\hline
\end{tabular}

Source: Donorejo’s Stakeholder Interview Data, 2020

The results of the ranking of development priorities of the fifth respondent are shown in Table 10. The public service is ranked first with a priority weight 0.611 . It is followed by human resource development with a priority weight 0.230 . The third is the regional promotion parameter with a priority weight 0.123 , and the last is the development of supporting infrastructure with a priority weight 0.035 .

Table 9. Calculation of the total weight of the parameters (Respondent 5)

\begin{tabular}{ccccc}
\hline Indicator & P1 & P2 & P3 & P4 \\
\hline P1 & 1,00 & 9,00 & 7,00 & 0,11 \\
P2 & 0,11 & 1,00 & 9,00 & 0,11 \\
P3 & 0,14 & 0,11 & 1.00 & 0.11 \\
P4 & 9.00 & 9.00 & 9.00 & 1.00 \\
\hline \multicolumn{5}{l}{ Source: Donorejo's Stakeholder Interview Data, 2020 }
\end{tabular}

Table 10. Normalized Data (Respondent 4)

\begin{tabular}{cccccc}
\hline Indicator & P1 & P2 & P3 & P4 & Weight \\
\hline P1 & 0,098 & 0,471 & 0,269 & 0,083 & 0,230 \\
P2 & 0,011 & 0,052 & 0,346 & 0,083 & 0,123 \\
P3 & 0,014 & 0,006 & 0,038 & 0,083 & 0,035 \\
P4 & 0,878 & 0,471 & 0,346 & 0,750 & 0,611 \\
\hline
\end{tabular}

Source: Donorejo's Stakeholder Interview Data, 2020

The results of the scoring from five stakeholders are shown in Figure 3. The graph shows some differences in the respondents' choices in determining the appropriate development priorities for Donorejo. This is caused by differences in the perceptions of each respondent regarding the scoring of the development priority factors of Donorejo.
Overall priority weights are obtained through the mean of each weight from the respondents. The results obtained are weight values and priority rankings of each parameter. Figure 4 shows that the development of supporting infrastructure is the top priority with a weight 0.375 or $37.5 \%$ of all parameters. The next priority is public service which has a weight of 0.292 or $29.2 \%$ of the total parameter. The third priority is the regional promotion with a weight of 0.204 or $20.4 \%$ of the total parameters. The development of human resources becomes the last priority with an average weight of 0.129 or $12.9 \%$ of the total parameters.

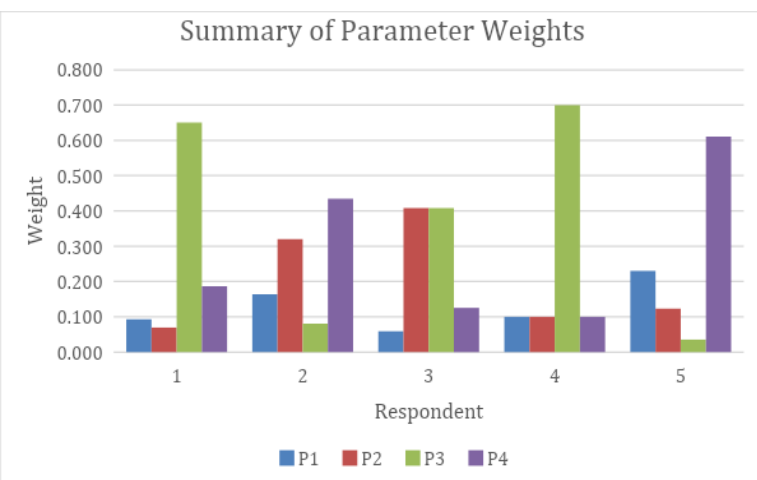

Fig.3. Diagram of Parameter Weights of All Respondents

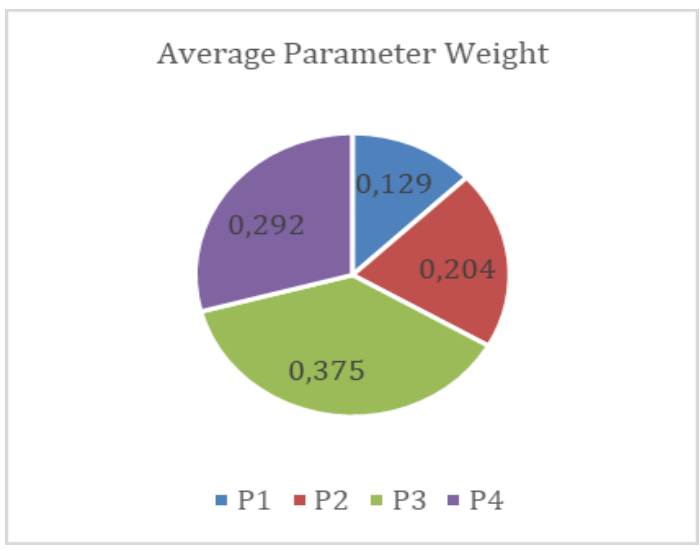

Fig.4. Diagram of Average Parameter Weights

The development of supporting infrastructure has become the main parameter in the development of Donorejo. The main infrastructure which can be developed is the maintenance of the road to the main tourism locations, especially Goa Seplawan. Based on interviews and observation, access to the tourism location is still inadequate to be passed by two cars and has much damage. The topography also caused some difficulties to access the location, especially during the rainy season. The development of supporting infrastructure becomes very important as road improvement to Goa Seplawan became one of the work plans in the Purworejo Regency Regional Government Work Plan (RKPD) 2020. Besides, good road access can also increase the economic growth in an area by facilitating the supply change. This strategy is reciprocal with the resolution of problems in Donorejo where economic conditions has been relatively low. 
The next aspect that becomes the priority of development is public services. In this case, the service referred to licensing and law enforcement in the bureaucratic chain. This aspect is closely related to funds received by the village in relation to Seplawan Goa's tourism revenue. Information from stakeholders stated that a number of visitors go to Goa Seplawan in each year is not very beneficial for Donorejo because of the difference in management of Goa Seplawan which is coordinated by Purworejo Regency.

The regional promotion aspect is the third aspect that becomes the development priority. The regional promotion through social media has not been intensively carried out by Donorejo to support its economy. In this case, the unavailability of young human resources to manage the village is one of the problems in the regional promotion. Meanwhile, the usage of various types of social media which are usually more easily used by young people. Regional promotion is directly related to the human resource development on the fourth priority. Older people who generally inhabit Donorejo can be trained to improve their abilities and skills in various ways. Some examples are skills that support tourism and agricultural productivity. Skills that support tourism such as making handicrafts from coffee or other typical plants as souvenirs from Goa Seplawan. Training for organizing activities such as art performances or puppet shows are also one of the skills which can be trained for the residents of Donorejo. The existence of this culture is also supported by the presence of qualified human resources and promotions related to various activities in Donorejo.

\section{Conclusion}

The AHP method can be used to determine priority development strategies in Donorejo Village. Based on the results of interviews with stakeholders in Donorejo and processing using the AHP method, The development of supporting infrastructure becomes the priority development strategy for Donorejo. The infrastructure can be developed in many ways, such as road repairs and maintenance of other supporting facilities. Improving roads quality to tourist attractions and roads that connect between villages can be an important priority for this development. In addition, the clarity of the bureaucracy in public services must also be improved. Increasing regional promotion and human resources in the usage of ICT can be done to support other aspects of development in Donorejo.

We appreciate the head of Donorejo and the hamlets who helped to find the right source and information. This research is one of the annual research result by EGSA expedition, Faculty of Geography, Universitas Gadjah Mada.

\section{References}

1. Direktorat Jenderal Bina Pemerintahan Desa Kementerian Dalam Negeri Republik Indonesia, Profil Desa Donorejo. (2020)

2. L. W. Santosa, Keistimewaan Yogyakarta dari Sudut Pandang Geomorfologi. Yogyakarta: Gadjah Mada University Press (2015), in Bahasa

3. Pemerintah Kabupaten Purworejo, RKPD Kabupaten Purworejo Tahun 2020, Purworejo: Pemerintah Kabupaten Purworejo (2019)

4. L. A. Larasati, N. M. Khoiruluswati, R. R. Aliyya, U. Widyanarko, R. F. Putri. Analytical Hierarchy Process for Regional Development Priority in Maluku Province, Indonesia. ASEAN Journal on Science \& Technology for Development (AJSTD) 36 (2) 57-63 (2019)

5. Z. Hareen, B. S. Widodo, Analysis of Tourism Development Potential AHP Approach (Analitycal Hierarchy Process) in the Types of Objects Nature Tourism, Cultural Tourism and Alternative Tourism in Bojonegoro Regency. Swara Bhumi 1 (2) 32-39 (2016)

6. T. L. Saaty, Decision Making for Leaders: The Analytic Hierarchy Process for Decisions in a Complex World. USA: RWS Publications. (2012)

7. L. O. A. M. Tumada, Analisis Strategis Pembangunan Kabupaten Muna. Thesis. Jakarta: Universitas Indonesia. (2012), in Bahasa

8. UNWTO. World tourism organization annual report 2016. Madrid: United Nations World Tourism Organization. (2016)

9. N. Rahman, H. B. S. E. Prakoso, Stakeholders Perspectives on the Potential Objects and Tourism Attractions (Odtw) of Ngebel Lake in Ponorogo Regency. Jurnal Bumi Indonesia 1 (1) (2012)

10. R. A. Saputri, H. Warsono, Evaluasi Dampak Sosial Ekonomi dalam Pengembangan Wisata Goa Seplawan di Kabupaten Purworejo. Journal of Public Policy And Management Review 6 (4) (2017) 